\title{
Investment Performance of Private Pension Funds in Selected Asian Countries: The Role of Fees and Management Companies
}

\author{
Loh Wen Yan ${ }^{1}$, Wong Mei Foong ${ }^{*}$ \\ ${ }^{\text {I} F a c u l t y ~ o f ~ A c c o u n t a n c y, ~ F i n a n c e ~ \& ~ B u s i n e s s, ~ T u n k u ~ A b d u l ~ R a h m a n ~ U n i v e r s i t y ~ C o l l e g e, ~ K u a l a ~ L u m p u r ~ 53300, ~}$ \\ Malaysia. \\ *Corresponding author. Email: wongmf@tarc.edu.my
}

\begin{abstract}
This paper examines the investment performance of private pension funds in Hong Kong, South Korea, Malaysia, Singapore, and Thailand, segregated by fund universe: Growth (equity), Moderate (balanced), and Conservative (bond) Fund. The adoption of hybrid model is a new attempt and all the three main categories of pension fund are evaluated in which previous studies have focused on merely equity funds. This study employs 6 years of monthly observations and a total of 931 pension-fund samples. Net returns and gross returns are used to evaluate the impact of fees on funds' performance with the hybrid model which mimics the Fama-French and Treynor-Mazuy. Empirical findings imply that most private pension funds in Asia have inferior performance even before the consideration of fees. In addition, the Growth Fund outperforms the Moderate and Conservative Fund before fees are taken into consideration. Nonetheless, management fees do deteriorate the performance of pension funds. Hence, policy makers should strive to devise suitable course of actions to raise the retirement incomes of citizen. Additionally, the results may be useful to investors to make better informed investment decisions and fund managers in building the pension fund's portfolio.
\end{abstract}

Keywords: Pension funds, Asset-pricing models, Fama and French, Treynor and Mazuy, Equities, Bonds, Mixed assets

\section{INTRODUCTION}

One of the most appropriate ways to improve the pension system of a country is the encouragement of additional savings platform such as private pension funds rather than merely depending on public pension schemes which could be unsustainable in long-term. The MMGPI 2019 report has revealed that the Asian region has pension systems that are deemed weaker due to the reasons such as the inadequacy of retirement savings, overly reliance on public pension funds, rapid aging population, and more. With that, the pension systems in most Asian countries have obtained the ratings below $\mathrm{B}$.

The establishment of private pension funds in Asia is largely due to the insufficient retirement savings of retirees and demographic profile in Asia. For instance, $41 \%$ of Malaysians rely on their Employee Provident Fund (EPF) savings as retirement income, while Saidi et al. [1] reported that about half of the retirees in Malaysia would deplete all their retirement savings within 5 years of retirement and more than $70 \%$ of EPF members aged 54 years old have savings of less than RM50,000 in their EPF account. Besides, the financial literacy of Malaysians is surprisingly low as $72 \%$ of the public do not have any retirement planning working-out ahead. This proves the inadequacy of retirement income and the lack of retirement planning among most Malaysians in achieving their retirement goals.
Moreover, the adequacy of retirement savings is a big concern for Thailand coupled with the rising costs of living, uptrend aging population, and low financial literacy of most Thailand workforce who lack the knowledge and importance of retirement planning. The average spending of retirees during retirement is approximately THB 8,000 on average while the maximum pension benefit an informal worker could receive is up to THB3,000 per month which is insufficient in covering the monthly spending when one retires. Hence, to reduce the overreliance on the public pension schemes and complement the retirement savings, there is an apparent need of the local Government in encouraging the engagement of private pension funds. Furthermore, in terms of the rapid demographic transition in Asia, Korea has the lowest fertility rate in the world with 0.92 per female and it is already deemed an "aged society" by the United Nations with $15.1 \%$ of population aged 65 years old and above. Korea is also forecasted to have the largest increase in aging population which is expected to further increase by $23 \%$ by year 2050 and become a "superaged' nation with $24.7 \%$ of older persons (United Nations, 2019) [2]. Besides, Department of Statistics Singapore (2019) reports that 1 out of 5 people is aged 65 years old or above and by year 2050, Singapore is expected to have $33.3 \%$ of population aged 65 or above and it is the second Asian country with largest increase in old-age population (United Nations, 2019) [2]. Besides, the fertility rate of the 
country has also dropped $7.5 \%$ since 2014 with the current average life expectancy of 83.2 years old.

As a result, the efforts of local Government in boosting the retirement savings through these voluntary private pension funds are apparent as incentives like tax exemptions that are offered to support this initiative. For instance, tax relief of up to RM3,000 per annuum is claimable for investing in private pension funds in Malaysia and according to Private Pension Administrator, the total number of Private Retirement Schemes (PRS) members grew by $38 \%$ in year 2018 which was largely contributed by the tax incentives. Hong Kong similarly allows up to $\operatorname{HK} \$ 60,000$ of taxdeductible income and a significant increase in additional contribution to pension savings is observed with this tax relief while the local policymakers in Korea and Singapore have also applied similar approach to enhance the retirement savings of the public.

Nonetheless, do these voluntary private pension funds generate returns that satisfy the needs of investors and allow them to build excess retirement income another way round beyond public pension funds? Empirically, Coggin et al. [3], Adami et al. [4] and Alda et al. [4] provided evidence on the outperformance of pension funds in the United Kingdom. Moreover, Chu and McKenzie [6] also provided similar findings in the context of Asia. Nonetheless, Ippoliyo and Turner [7], Bohl et al. [8] provided contradictory findings and demonstrated the inferior performance of pension funds.

In addition, the nature of private pension funds in Asia is the actively managed funds that often comes with a fee structure comprising of annual management fees, sales fees, exit fees, loading fees, and more which is like a mutual fund. A study by Mansor et al. [9] demonstrated the significant role of fees in deteriorating the performance of mutual funds and researchers like Haslem et al. [10], Bauer and Kicken [11] and Gil-Bazo et al. [12] have also found similar results, while Alda and Ferruz [13] provided evidence on the impact of fees on pension funds. Hence, the impact of fees on the performance of private pension funds may adversely deteriorate the returns of funds to investors and should be critically examined.

Many Asian retirement-income systems are ill-prepared for the rapid population ageing that will occur over the next two decades. Hence, private pension funds may be the appropriate saving vehicles that could complement the retirement savings of retirees. Nevertheless, there is only little empirical evidence found to support this idea as only Chu and McKenzie [5] have shown the outperformance of equity pension funds in Hong Kong. Hence, despite the empirical evidence of the outperformance of pension funds in developed countries like the U.K and U.S (Coggin et al. [3], Adami et al. [4] and Alda et al. [5]), the presence of superiority of pension funds in Asia is not proven.

Besides, previous studies which have shed lights on this research area have mainly prioritized on equity funds (Coggin et al. [3], Chu and McKenzie [6], Alda et al. [5]), as only Adami et al. [4] has examined the performance of pension funds in the bond universe. The exigency in examining all categories of pension funds is equally critical to ease the investment decision of investors. Also, policy- makers may reformulate the approaches in elevating the retirement savings of investors while fund managers are able to understand the factors impacting the returns of pension funds and build portfolios accordingly.

Lastly, this paper contributes to the existing literature-body by providing empirical evidence on the performance of private pension funds in Asia which is paid little attention to since this industry in Asia, especially Malaysia and Thailand, is indeed very small coincided with the short history of Malaysian private pension funds, which may easily be overlooked. Besides, as previous studies demonstrated evidence on merely the performance of equity pension funds, this paper contributes to the existing literature by including the balanced funds and bond funds, evaluating all the three main categories of pension funds available: Growth (equity), Moderate (mixed assets) and Conservative (bond) Fund. In addition, the use of the hybrid model of Fama-French and Treynor-Mazuy is a new attempt in capturing the performance of pension funds.

\subsection{Paper Structure}

The rest of this paper is organized as follows. Section 2 provides the review on related literature. Section 3 presents the description of data and methodology. Then Section 4 discusses the results and conducts further analyses and robustness tests. Finally, Section 5 concludes the paper.

\section{LITERATURE REVIEW}

Ippolito and Turner [7] adopted the Capital Asset Pricing Model (CAPM) and asserted that private pension funds in the United States had inferior performance when being compared to the market index proxied by S\&P500 while a superior performance was observed when being benchmarked against the bond index. Also, the researchers compared the performance of pension funds and mutual funds, which documented that private pension funds underperform mutual funds by approximately $3 \%$. Nonetheless, it was pointed out that CAPM may be an insufficient model in capturing the funds' returns. These findings are in line with Lakonishok et al. [14] which also documented the underperformance of U.S pension funds.

The usage of single-factor model was then slowly diminished, and market-timing factor was observed to be widely adopted by researchers to capture the performance of pension funds. For instance, a study by Coggin et al. [3] on United States equity pension funds for the selectivity and market-timing skills of the fund managers. Using the Treynor-Mazuy and Bhattacharya-Pfleiderer model, it was concluded that the selectivity ability of fund managers is positive while the timing ability is inferior on average which implies pension fund managers are not equipped with the market-timing skills.

Moreover, Brown et al. [15] found no evidence of markettiming effect in the United Kingdom pension funds. The authors adopted the Henriksson-Merton model with less than $3 \%$ of the samples that have generated significant market-timing ability. An empirical study by Thomas and 
Tonks [16] on U.K equity pension funds has shown that most pension funds regressed with CAPM have generated positive but insignificant alphas while the average betas are close to 1 , which indicates that the samples do move closely with the market. Besides, both the Treynor-Mazuy and Merton-Henriksson model have demonstrated consistent results that market-timing ability is inferior with significant negative alphas. Antolin [17] on the other hand found that the private pension funds in OECD have inferior performance.

Meanwhile, more recent researches demonstrated a trend towards multi-factor models in explaining the performance of pension funds returns. For instance, a study by Adami et al. [4] has tested the performance of U.K pension funds using three performance models: CAPM, Fama-French 3Factor model, and Carhart 4-factor model. The results of CAPM demonstrated significant alphas for both equity and bond funds. Using the FF3FM, the explanatory power is enhanced with significant positive alphas and a positive size premium is present while value premium is negative. Adding the momentum factor in Carhart model does not change the sign of alphas, however, it still does not increase the explanatory power as the momentum factor is insignificant. Also, the performance of pension funds with gross and net returns are comparably positive which indicates that fees do not have a large impact on the pension funds' performance.

In addition, a study by Alda et al. [5] adopted the CAPM and Carhart 4-Factor model and indicates the outperformance of the U.K pension funds and only the momentum factor is negative whereas the other factors are positive. Moreover, the study has also incorporated personal traits like gender and the experience of fund managers, and it was found that these personal traits do not have any significant impact on funds' performance, while management strategy such as specialization skill enables the managers to perform better than do the generalized managers.

Apart from private pension funds, the performance of public pension fund has also been covered in past studies. Bohl et al. [8] documented the performance of mandatory pension funds in Poland and Hungary and consistently generated significant negative Jensen's alpha in Hungary across all the three models: CAPM, Treynor-Mazuy, and HenrikssonMerton, while the performance of Poland is inconclusive with little evidence of outperformance. Also, Lieksnis [18] found that pension fund managers do not possess the market-timing skills.

In addition, a study conducted by Chu and McKenzie [6] focused on the performance of Hong Kong's Mandatory Provident Funds (MPF) with primary focus on equity fund universe. It was found by the researchers that the MPF equity funds do have superior returns on average. The fund managers were also found to possess superior markettiming skills using the Treynor-Mazuy and HenrikssonMerton models in which the two market-timing models produced consistent results.

Rashid and San [19] found that EPF outperformed the market, but fund managers do not possess the market-timing skills. Moreover, the performance of public pension funds was also compared among Asian countries. Ahmad and Nor [20]'s study on the public pension funds in Malaysia, Singapore, South Korea, and Hong Kong from the year 2000 to 2011 has found that Singapore's Central Provident Fund (CPF) is among the four pension funds that earns the highest return proxied by Return on Investment despite that it is the most conservative investment that invest primarily in the country's treasury securities. Meanwhile, Mandatory Pension Fund (MPF) in Hong Kong earns the lowest return being the most aggressive fund that invests largely in equity market.

Hence, the present study aimed to rectify these literature gaps by exploring a wider categories of pension funds which can be categorised into growth fund, moderate fund, and conservative fund. This study was conducted based on selected Asian countries and adopted a hybrid model which mimics the Fama-French and Treynor Mazuy models.

\section{DATA AND METHODOLOGY}

This research covers five selected countries in Asian region, i.e., Malaysia, Singapore, Hong Kong, South Korea, and Thailand. The private pension funds of these countries are further segregated into three major fund-groups according to its fund universe: Growth (equity) Funds, Moderate (balanced) Funds, and Conservative (bond) Funds. A 6-year sample period was employed, and each fund group would consist of 72 monthly observations of equally-weighted portfolio. The performance of pension funds was captured using the hybrid of two standard performance models: The Fama-French and Treynor-Mazuy model, regressed with both time-series and panel regressions.

The private pension funds were filtered according to the below selection criteria by excluding: (1) Funds classified as "others" or unclear specification of fund type; (2) Funds with less than 6 years of history; (3) Funds with incomplete monthly data of 6 years; (4) Funds that are Shariah compliant (Islamic pension funds), and (5) Funds that are sector specific such as REITs funds.

The data for this study was gathered from various sources. We obtained financial data from various reliable sources, i.e., Central Provident Fund, Thomson Reuters Eikon, Central Bank of South Korea, Central Bank of Thailand, Morgan Stanley Capital International (MSCI), S\&P Global. Our final sample consists of 931 private pension funds, with 326 pension funds were sampled from Hong Kong. We also sampled 328 Korean funds, 39 Malaysian funds, 132 Singapore funds, and 106 Thailand funds.

The performance of private pension funds was captured using the hybrid model of two standard performance models: The Fama and French (1993) factor-model as well as The Treynor and Mazuy (1966) market-timing model. Since the original Fama-French model was dedicated to explain the variations of equity returns while to study bond returns, Term and Def were added as the term-structure risk factors that capture the term premium and default premium in bonds. The specification of the hybrid model is derived as follows: 
Growth Fund:

$R_{i, t}-R_{f, t}=\alpha_{i}+\beta_{i}\left(M R P_{t}\right)+s_{i} S M B_{t}+h_{i} H M L_{t}+t m_{i}\left(M R P_{t}\right)^{2}+\varepsilon_{i, t}(1)$

\section{Moderate Fund and Conservative Fund:}

$R_{i, t}-R_{f, t}=\alpha_{i}+\beta_{i}\left(M R P_{t}\right)+s_{i} S M B_{t}+h_{i} H M L_{t}+t m_{i}\left(M R P_{t}\right)^{2}+t_{i}$ Term $_{t}$ $+d_{i}$ Def $_{t}+\varepsilon_{i, t}$

whereas $R_{i, t}-R_{f, t}$ is risk-adjusted return of pension funds at period $t, \mathrm{MRP}_{\mathrm{t}}$ is excess return on the market, $\mathrm{SMB}_{\mathrm{t}}$ is return of small-cap stocks minus large-cap stocks, $\mathrm{HML}_{\mathrm{t}}$ is return of value stocks minus growth stocks, $\mathrm{MRP}_{\mathrm{t}}^{2}$ is squared of excess return on the market, Term $_{t}$ is 10 -year government bond yield minus 3-month Treasury bill rate, Def $_{t}$ is corporate bond return minus 10-year government bond yield, $\alpha_{\mathrm{i}}$ is Jensen's alpha (performance measure), $\beta_{\mathrm{i}}$ is market risk premium, $s_{i}$ is size premium, $h_{i}$ is value premium, $\mathrm{tm}_{\mathrm{i}}$ is market timing ability, $\mathrm{t}_{\mathrm{i}}$ is term premium, $\mathrm{d}_{\mathrm{i}}$ is default premium, and $\varepsilon_{\mathrm{i}, \mathrm{t}}$ is random error-term.

The Growth Fund was regressed with Equation (1) with 4 independent variables while both the Moderate and Conservative Fund were regressed with Equation (2) with 6 independent variables as 2 bond factors were included to capture the bond investments. The market timing in Treynor and Mazuy model was based on the idea that managers can predict the market trend by timing the market in generating higher fund returns. According to Fama and French [20], the intercept or alpha generated in the model may be used to capture any abnormal excess returns and to measure the skills of fund managers by beating the market. Hence, investors may be guided in selecting the most outperforming investment. Both net return and gross return of private pension funds were computed to evaluate the performance before and after the consideration of fees.

Diagnostic checks were conducted such as testing for heteroscedasticity using White (1980) test, autocorrelation using Durbin Watson for time-series regressions while Wooldridge (2010) test was used for panel regressions, and multicollinearity test using Variance Inflation Factors (VIF) test. None of the models suffered from multicollinearity effect, but heteroscedasticity and autocorrelation issues were present which would then be rectified using Newey West Standard Error for time-series regressions while Robust and Cluster Standard Error were used for panel regressions.

\section{RESULTS AND DISCUSSION}

\subsection{Descriptive statistics}

Table 1 reports the univariate analysis of descriptive statistics and correlation matrix. All fund groups across five countries have negative mean values for both gross and net returns. Besides, the mean value of Growth Fund is the least negative, followed by Moderate then Conservative Fund, and this is consistent in every country. The standard deviation of gross and net return is the highest in Growth Fund, followed by Moderate and Conservative Fund, which is also consistent in every country. The least negative mean value of both gross and net returns for all fund types is Hong
Kong, with mean values ranging from $-0.1892 \%$ to $0.7019 \%$, and Hong Kong also has the highest standard deviations in the returns of Growth and Conservative Fund which is $4.0540 \%$ and $0.8460 \%$, respectively. Meanwhile, the most negative mean value of both gross and net returns of all fund types is Malaysia, with mean values ranging from $-2.8168 \%$ to $-3.0590 \%$. The highest standard deviation in the returns of Moderate Fund is $2.1752 \%$ in Thailand. The lowest standard deviation in the returns of Growth Fund is $1.8722 \%$ in Malaysia, while Korea has the lowest standard deviation of $1.2064 \%$ in Moderate Fund and Thailand has the lowest standard deviation of $0.2728 \%$ in Conservative Fund. Besides, the correlation matrix reported imply that the multicollinearity effect does not exist as the correlations between the variables are low and below 0.8 .

\begin{tabular}{|c|c|c|c|c|c|c|}
\hline Country & Fund type & Variables & Mean & Std. Dev. & Min & Max \\
\hline & Growth Fund & NetRetum & -0.0030 & 0.0405 & -0.1139 & 0.0896 \\
\hline \multirow[t]{5}{*}{ Hong Kong } & & GrossReturn & -0.0019 & 0.0405 & -0.1128 & 0.0907 \\
\hline & Moderate Fund & NetReturn & -0.0052 & 0.0199 & -0.0662 & 0.0408 \\
\hline & & GrossReturn & -0.0041 & 0.0199 & -0.0651 & 0.0419 \\
\hline & Conservative Fund & NetReturn & -0.0070 & 0.0085 & -0.0245 & 0.0089 \\
\hline & & GrossRetwon & -0.0061 & 0.0085 & -0.0236 & 0.0098 \\
\hline \multirow[t]{6}{*}{ South Korea } & Growth Fund & NetRetum & -0.0165 & 0.0318 & -0.1407 & 0.0410 \\
\hline & & GrossRetwon & -0.0161 & 0.0318 & -0.1403 & 0.0414 \\
\hline & Moderate Fund & NetRetum & -0.0173 & 0.0121 & -0.0639 & 0.0045 \\
\hline & & GrossRettum & -0.0170 & 0.0121 & -0.0637 & 0.0047 \\
\hline & Conservative Fund & NetRetumn & -0.0179 & 0.0081 & -0.0736 & -0.0071 \\
\hline & & GrossReturn & -0.0178 & 0.0081 & -0.0735 & -0.0070 \\
\hline \multirow[t]{6}{*}{ Malaysia } & Growth Fund & NetRetum & -0.0294 & 0.0187 & -0.0948 & 0.0009 \\
\hline & & GrossReturn & -0.0282 & 0.0187 & -0.0935 & 0.0021 \\
\hline & Moderate Fund & NetRetum & -0.0306 & 0.0144 & -0.0787 & -0.0050 \\
\hline & & GrossRetwon & -0.0294 & 0.0144 & -0.0775 & -0.0038 \\
\hline & Conservative Fund & NetReturn & -0.0301 & 0.0055 & -0.0499 & -0.0215 \\
\hline & & GrossReturn & -0.0290 & 0.0055 & -0.0488 & -0.0204 \\
\hline \multirow[t]{6}{*}{ Singapore } & Growth Fund & NetRetum & -0.0084 & 0.0283 & -0.0982 & 0.0451 \\
\hline & & GrossRetion & -0.0056 & 0.0283 & -0.0955 & 0.0478 \\
\hline & Moderate Fund & NetRetum & -0.0103 & 0.0169 & -0.0674 & 0.0211 \\
\hline & & GrossRetwon & -0.0069 & 0.0169 & -0.0639 & 0.0245 \\
\hline & Consemative Fund & NetRetum & -0.0106 & 0.0083 & -0.0320 & 0.0071 \\
\hline & & GrossReturn & -0.0086 & 0.0083 & -0.0300 & 0.0091 \\
\hline \multirow[t]{6}{*}{ Thailand } & Growth Fund & NetRetum & -0.0125 & 0.0267 & -0.0722 & 0.0490 \\
\hline & & GrossRetwen & -0.0112 & 0.0267 & -0.0709 & 0.0502 \\
\hline & Moderate Fund & NetRetum & -0.0136 & 0.0218 & -0.0619 & 0.0284 \\
\hline & & GrossReturn & -0.0123 & 0.0218 & -0.0606 & 0.0296 \\
\hline & Conservative Fund & NetRetum & -0.0146 & 0.0027 & -0.0218 & -0.0088 \\
\hline & & GrossReturn & -0.0141 & 0.0027 & -0.0213 & -0.0083 \\
\hline
\end{tabular}

\subsection{Main regression results}

The time-series regression results are reported in Table 2 . In general, only two funds in the Growth universe from Singapore $(\alpha=0.0044)$ and Hong Kong $(\alpha=0.0032)$ are significantly positive using gross return, while other funds have mostly generated insignificant or negative alphas. This indicates that most private pension funds in Asia have inferior performance that are unable to generate abnormal excess returns to investors even before the consideration of fees. Hence, investors anticipating building retirement income beyond public pension schemes through additional savings with private pension funds should reconsider this investment decision as they do not help accumulating their retirement wealth in general.

Moreover, fees do further deteriorate the performance of private pension funds as the alpha values become more negative when net returns are used, and several insignificant positive alphas have turned negative. This implies that fees 
do adversely impact the performance of funds which is consistent with the studies by Alda and Ferruz [12], Mansor et al. [8]. In addition, the market risk premium across all fund types and countries are below 1 ranging from 0.0008 to 0.87 with the highest risk in Growth, and then followed by the Moderate and Conservative Fund. The size premium is present in most fund groups and countries while value premium and market-timing skill are mostly absent. The term and default premium are also mostly present in the Moderate and Conservative Fund across all countries.

\begin{tabular}{|c|c|c|c|c|c|c|}
\hline Fund type & Variable & Honghong & Eorea & Malaysia & Singapore & Thailand \\
\hline \multirow{5}{*}{ Growth Fund } & Conertayts & 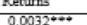 & $-0,024$ & $-0.114^{+\infty}$ & $0,0044^{* 0}$ & -0.018 \\
\hline & MRPP & 0.790. & $0.87 \cdots$ & $0.52 \ldots$ & $0.71 \cdots$ & $0.82 \ldots$ \\
\hline & $S . M B$ & $0.10 \cdots$ & $0.05^{*}$ & 0.44 & $0.32 \ldots$ & 0.03 \\
\hline & 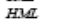 & & -0.003 & -0.044 & 0.015 & 0.03 \\
\hline & & $-0.61^{*}$ & & -0.41 & $-1.84^{4 *}$ & \\
\hline \multirow[t]{7}{*}{ Moderate Fund } & Constant & -0.0009 & -0.0056 & $-0.0262 *$ & 0.0024 & 0.0003 \\
\hline & & $0.34 \cdots$ & $0.33 \cdots$ & $0.39+\ldots$ & 0.35 w.* & $0.69+\ldots$ \\
\hline & $S M B B$ & 0.02 & 0.02 & $0.36+\cdots$ & $0.15 \ldots$ & \\
\hline & $H M I$ & -0.01 & -0.006 & 0.043 & -0.008 & -0.048 \\
\hline & ARP & -0.27 & -0.001 & -0.41 & -0.78 & 0.44 \\
\hline & Term & $0.44 \cdots$ & & -0.35 & $0.73 \cdots$ & \\
\hline & & $0.40^{* *}$ & $0.36 \cdots$ & & $0.66^{* *}$ & $0.35^{* *}$ \\
\hline \multirow{8}{*}{$\begin{array}{l}\text { Conservative } \\
\text { Fund }\end{array}$} & Constant & $-0.0046^{* * *}$ & -0.0036 & -0.0017 & 0.0008 & $-0.0088^{* \cdots *}$ \\
\hline & $M Q P P$ & $0.04 \cdots$ & -0.03 & $0.14 \cdots$ & 0.0006 & $0.02 *-$ \\
\hline & $S M B$ & -0.03 & $-0.04^{*}$ & $0.08+\ldots$ & $0.04^{*}$ & -0.008 \\
\hline & & & & & & \\
\hline & & & & & & \\
\hline & Term & 0.8600 & $1.25 \%$ & 0.6500. & $0.99+\ldots$ & 0.2700. \\
\hline & & 0.77 & 1.08 & $0.78+\cdots$ & $1.09+\ldots$ & $0.36 \cdots$ \\
\hline & Panel B: $N$ & enums & & & & \\
\hline \multirow{5}{*}{ Growth Fund } & Constront & $0.0022^{*}$ & $-0.0028^{*}$ & $-0.0127^{* 20}$ & 0.0016 & $-0.0031^{102}$ \\
\hline & $M R^{P}$ & $0.79+2.0$ & $0.87+0.4$ & $0.52 \ldots$ & $0.71 \ldots$ & $0.82 \ldots$ \\
\hline & $S: M B$ & 0.100 .0 & $0.05^{*}$ & $0.44 \ldots$ & $0.32 \ldots$ & \\
\hline & $H \cup \pi$ & 0.007 & -0.003 & -0.044 & 0.015 & 0.03 \\
\hline & arps & $-0.61 *$ & -0.13 & -0.41 & $-1.84 \div$ & \\
\hline \multirow[t]{7}{*}{ Moderate Fund } & Constount & -0.002 & $-0.0059+\cdots$ & $-0.0274^{* *}$ & -0.001 & -0.0009 \\
\hline & & $0.34 \cdots$ & $0.33 \cdots$ & $0.39+\ldots$ & $0.35 \%$ & $0.69 \%$ \\
\hline & $S: M B$ & 0.02 & 0.02 & $0.36+\cdots$ & $0.15^{* * * *}$ & 0.04 \\
\hline & $\mathrm{H} M \mathrm{MI}$ & -0.01 & -0.006 & 0.043 & -0.008 & -0.048 \\
\hline & MQRP & -0.27 & -0.001 & -0.41 & -0.78 & 0.44 \\
\hline & Term & $0.44 \cdots$ & 0.18 & -0.35 & $0.73^{* \ldots * *}$ & \\
\hline & $D e f$ & $0.40^{\circ+\infty}$ & $0.36 \cdots$ & -0.36 & $0.66^{* *}$ & $0.35^{\circ *}$ \\
\hline \multirow{7}{*}{$\begin{array}{l}\text { Conservative } \\
\text { Fund }\end{array}$} & Constaut & $-0.0054 * \cdots$ & -0.0038 & -0.0028 & -0.0013 & $-0.0093 * \ldots$ \\
\hline & & $0.04 \cdots$ & -0.03 & $0.14 \cdots$ & 0.0006 & $0.02^{* *}$ \\
\hline & $S M A B$ & -0.03 & - & 0.08 & $0.044^{*}$ & -0.008 \\
\hline & $H M I$ & -0.01 & -0.04 & -0.02 & -0.02 & 0.01 \\
\hline & MQPP & 0.13 & -0.16 & -0.42 & & \\
\hline & Term & $0.86 \cdots$ & $1.25 \cdots$ & $0.65+\cdots$ & $0.99+\ldots$ & 0.2700. \\
\hline & Def & $0.77 \cdots$ & $1.08+\cdots$ & $0.78+\ldots$ & $1.09+\ldots$ & $0.36 \cdots$ \\
\hline
\end{tabular}

The panel regression results are presented in Table 3 . The beta coefficients of market risk premium are less than 1 across all fund groups with the highest of 0.752 in Growth Fund, followed by 0.398 in Moderate Fund and the lowest of 0.023 in Conservative Fund. This is consistent with the investment objectives of pension funds regardless of fund universe as pension funds should indeed be conservative in nature to safeguard the interest of investors. Hence, despite Growth Fund being the most "aggressive" among all pension fund categories, it is still considered a safe and low risk investment for retirement, since the risk is lower than that of the overall market. Moreover, the performance of pension funds using gross return is the best in Growth Fund $(\alpha=0.0057)$, followed by Moderate Fund $(\alpha=0.0003)$ then Conservative Fund $(\alpha=-0.0028)$, implying that Growth Fund has superior investment performance while Moderate and Conservative Fund are inferior with insignificantly positive and negative alpha, respectively. The outperformance of equity pension funds is consistent with Coggin et al. [3], Chu and McKenzie [6], Adami et al. [4] and Alda et al. [5] while the underperformance of pension funds is in line with Ippolito and Turner [7], Lakonishok et al. [14], Antolin [17] and Bohl et al. [8]. The beta coefficient of market risk premium is 0.023 in Conservative Fund, which is interestingly close to 0 . Hence, Conservative Fund is a low-risk investment and it is likely that the bond investments of pension funds are largely made up of Treasury Bonds and Investment-Grade bonds. As a result, the large investment proportion in low-risk bonds which resulted in a low beta also contributes to the inferior performance of Conservative pension funds. Despite the conservative investment style which is indeed in line with the investment objective of Conservative Fund, the return however is dissatisfying as the alpha of gross return is already negative even before the consideration of fees.

Moreover, management fees do deteriorate the performance of pension funds since the alphas between the gross and net return models have changed from positive to negative in both the Growth and Moderate Funds.

This is parallel with the studies by Bauer and Kicken [11], Alda and Ferruz [13], Mansor et al. [9]. Interestingly, all fund groups generated negative alphas using net return, but Moderate Fund has the least negative alpha, followed by Growth Fund and then Conservative Fund. This indicates that management fee charged in Growth Fund is higher than that in Moderate Fund which may be due to the frequent rebalancing of stocks required in equity portfolio by fund managers as compared to the balanced and bond investments.

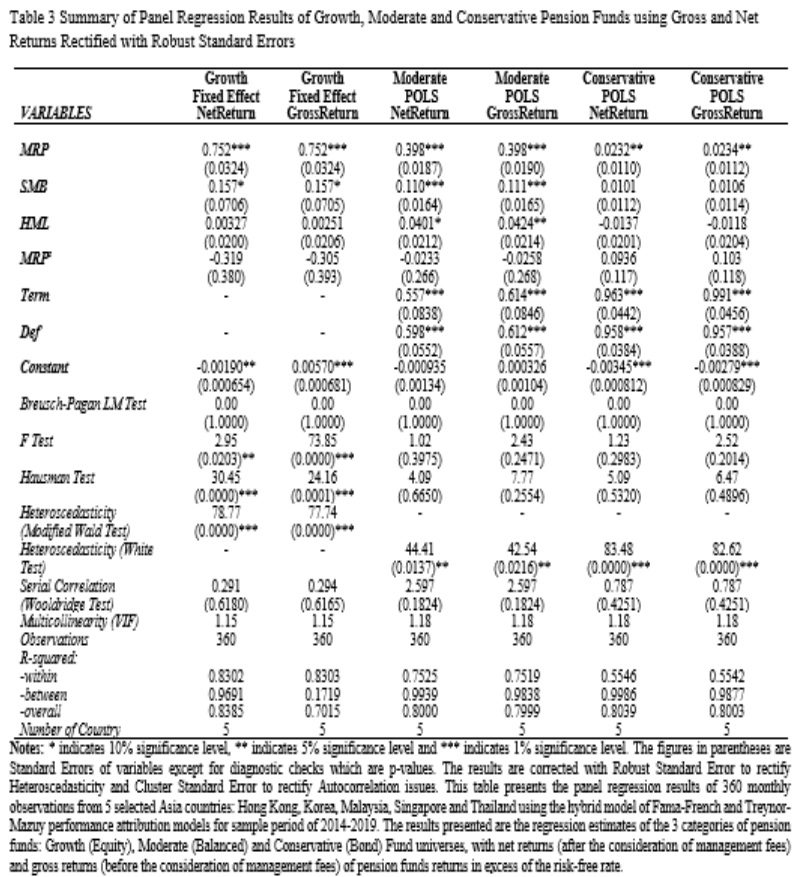

The Fama-French equity factor, $S M B$ is found to be positively present in Growth Fund with a weak evidence of $10 \%$ significance level and this implies that the fund managers do hold some small-cap stocks in the equity portfolio that could increase the performance of pension funds as size premium is present. This is consistent with the studies conducted by Adami et al. [4] and Alda et al. [5] Moreover, $H M L$ is found to be absent in Growth Fund. This is parallel with the studies by Fama and French [21] 
concluding that value premium is not often present. The size and value premium are however both present in Moderate Fund which add the value to Moderate Fund by elevating its performance in generating positive but insignificant alpha. In addition, the slope of Term is higher when Government Bonds with longer maturity and corporate bonds are included, since they are more sensitive to the changes in term structure and hence become the subjects to higher interest-rate risk. Besides, the slope of Def is higher when more corporate bonds are included since they have higher default risk than the Government Bonds [21]. By this way, the empirical results suggest that Conservative Fund in Asia have a high exposure in Corporate Bonds and Government Bonds with longer maturity since both bond factors have the slopes close to 1 . Nonetheless, the two equity factors $-S M B$ and $H M L$ are insignificant in bond universe which implies that they do not explain the variations of bond returns which contradicts with Fama and French [21]. On the other hand, both the Term and Def factors representing term premium and default premium are present in Moderate Fund, but with coefficients lower than those in Conservative Fund. The slope of Term ranges around 0.5 suggesting that the bond investments in Moderate Fund comprises of shorter-term Government Bonds with shorter maturity while the slope of Def which also lingers between 0.5 implies that the proportion of Government Bonds included in the balanced portfolio is likely to be higher than that of Corporate Bonds. Nevertheless, the market-timing skill is absent across all fund groups as it is statistically insignificant. This is consistent with the studies by Coggin et al. [3]. The FamaFrench three equity factors and two bond factors capture the Moderate Fund group best since all 5 factors are significant in the Moderate Fund and the explanatory power of the model is 0.80 as measured by R-Squared. Besides, the performance of Conservative Fund is largely explained by the market risk premium and Fama-French bond factors producing R-Squared of 0.80 while the equity factors do not seem to explain the variations of bond performance. Meanwhile, the performance of Growth Fund on the other hand is mainly explained by the market risk premium and size premium, but not value premium.

\section{CONCLUSION}

This paper has examined the investment performance of private pension funds in five Asian countries: Hong Kong, South Korea, Malaysia, Singapore, and Thailand, as segregated by fund universe: Growth, Moderate and Conservative Fund. We employed a study period of 6 years with monthly observations of 72 and a total of 931 pension fund samples. The management fees charged against the gross return of pension funds were taken into consideration to compare the performance of funds before and after the fees are charged. Part of the originality of this paper is due to the use of the hybrid model as obtained from FamaFrench and Treynor-Mazuy which mimics the Fama and French [21] factors and the market-timing skills of fund managers.
Using the time-series OLS estimator, it is concluded that most private pension funds in these five Asian countries have inferior performance even before the consideration of fees since the alphas generated were mostly negative with only Hong Kong and Singapore generating significant positive alpha in Growth Fund. Hence, the private pension funds in these five Asian countries are unable to help investors in building extra retirement wealth on average. Moreover, the systematic risk of all private pension funds across all countries and all fund categories are lower than that of the overall market since the beta coefficients of market risk premium are less than 1 , which is in line with the investment objectives and prudent nature of pension funds.

Using panel regressions, only Growth Fund has abnormal excess returns while Conservative Fund has inferior performance before fees are charged, and Moderate Fund yielded inconclusive results with insignificant positive alpha. Nonetheless, all the three fund types exhibit inferior performance when fees are taken into consideration implying that investors do not enjoy additional excess returns from private pension funds. Nonetheless, Growth Fund has better investment performance than do the Moderate and Conservative Fund which is justifiable as Growth Fund is more aggressive with equity investments, while Moderate Fund is a balanced investment, and Conservative Fund is the most conservative with bond investments.

Furthermore, management fees charged by fund managers do significantly deteriorate the performance of pension funds. Interestingly, the gap between alphas using gross and net returns is wider in Growth Fund. This is possibly due to the higher fee charged in Growth Fund as equity portfolios requires more frequent analysis and rebalancing than do the bond portfolios. This finding perhaps could unlock a new dimension of incorporating passively the managed technique to pension fund portfolios in order to reduce the fees chargeable to investors.

Besides, size factor does capture the performance of equity pension funds but not the bond pension funds, while value factor on the other hand is seemingly redundant across most fund types. Hence, both equity and bond investments do not share common risk factors since the equity factors do not capture the bond investments in Conservative Fund. Both term and default premium on the other hand work extremely well in capturing the variations of the performance of bond pension funds. Meanwhile, these findings also suggest that the market-timing skills of fund managers are absent across all fund categories.

This paper fills the research gaps by examining the performance of private pension funds in Asian region which was overlooked by past studies. In addition, all three main categories of pension funds were evaluated in this study in which bond and balanced funds were paid little attention to previously. Besides, the adoption of hybrid model incorporating the two standard performance models is a new attempt. Following the recommendations of future research highlighted by Adami et al. [4], this paper includes the default premium, Def which was previously excluded by the researchers due to data unavailability. Hence, the 
reformed model is believed to enhance the regression results and its explanatory power.

The findings of this paper provide insights to investors in reconsidering to invest in these voluntary private pension funds as they have inferior performance. Furthermore, these findings may allow fund managers to build pension fund portfolios by reformulating their investment strategies and perhaps using investing factors to achieve the outperformance of funds according to the presence of factor premiums. Moreover, these findings may have implications to policy makers in reformulating the approaches used to elevate the retirement incomes of investors as private pension funds that are highly encouraged do not seem to earn appealing returns.

Nevertheless, the study period of 6 years employed is rather a short duration. In addition, past similar studies have employed longer study periods often exceeding 10 years which produced the results that might contradict with this paper due to the inconsistency of sample period. Moreover, there seems to be a lack of existing literature body examining the performance of private pension funds in Asia especially South Korea, Malaysia, and Thailand. Hence, similar findings are difficult to be found as evidence to support the arguments and findings of this paper.

By this way, the performance of private pension funds in Asia should be revisited especially when the data of at least 10 years may be available and collected. Moreover, future research may employ various other standard performance models such as the Carhart 4-factor model and Fama and French 5-factor model by incorporating additional factors as independent variables like the Momentum factor to enhance the explanatory power of the model.

However, since only management fees were taken into consideration in this study, future research may also include sales fee, loading fee, redemption fee, and other fees to test the impact of different fee structure on the performance of pension funds. Lastly, future research may also incorporate the bond factors - term and default premium in evaluating the performance of Growth Fund, since Fama and French [20] provides evidence on the common factors shared between equity and bond investments in an integrated market.

\section{REFERENCES}

[1] N.A.N. Saidi, M.M. Yusuf, M.Y.A. Basah, Assessing the adequacy of contribution rates towards employees' provident fund in Malaysia, in: Z.H. Zamzuri, F.A. Razak, W.Z. Zin, S.C. Dzul-Kifli (Eds.), Proceedings of the 4th International Conference on Mathematical Sciences, AIP Publishing, Putrajaya, Malaysia, 2017, pp. 4-6. DOI: https://doi.org/10.1063/1.4980934

[2] United Nations, World Population Ageing (2019). https://www.un.org/en/development/desa/population/pu blications/pdf/ageing/WorldPopulationAgeing2019Highlights.pdf
[3] T.D. Coggin, F.J. Fabozzi, S. Rahman, The investment performance of U.S. equity pension fund managers: An empirical investigation, J. Fin. 48(3) (1993) 1040-1055. DOI: https://doi.org/10.1111/j.15406261.1993.tb04029.x

[4] R. Adami, O. Gough, S. Mukherjee, S. Sivaprasad, An empirical analysis of the performance of pension funds: evidence from UK, Stud. in Econ. Fin. 31(2) (2014) 141-155. DOI: https://doi.org/10.1108/SEF-102012-0118

[5] M. Alda, L. Andreu, J.L. Sarto, Learning about individual managers' performance in UK pension funds: The importance of specialization, North A. J. Econ. Fin. 42 (2017) 654-667. DOI: https://doi.org/10.1016/j.najef.2017.09.006

[6] P.K.K. Chu, M. McKenzie, A study on stockselection and market-timing performance: Evidence from Hong Kong Mandatory Provident Funds, Rev. Pac. Bas. Fin. M. P. 11(4) (2008), 617-649. DOI: https://doi.org/10.1142/S0219091508001507

[7] R.A. Ippolito, J.A. Turner, Turnover, fees and pension plan performance, Fin. Anal. J. 43(6) (1987), 16-26. DOI: https://doi.org/10.1007/BF03399252

[8] M.T. Bohl, J. Lischewski, S.Voronkova, Pension funds' performance in strongly regulated industries in Central Europe: Evidence from Poland and Hungary, Emerg. M. Fin. Trad. 47(3) (2011), 80-94. DOI: https://doi.org/10.2753/REE1540-496X4704S305

[9] F. Mansor, M.I. Bhatti, M. Ariff, New evidence on the impact of fees on mutual fund performance of two types of funds, J. Int. Fin. Mark. Ins. M. 35(C) (2015), 102-115. DOI:10.1016/j.intfin.2014.12.009

[10] J.A. Haslem, H.K. Baker, D.M Smith, Performance and characteristics of actively managed retail equity mutual funds with diverse expense ratios, Fin. Serv. Rev. 17(1) (2008), 49. DOI:10.2139/ssrn.1128983

[11] R. Bauer, L. Kicken, The pension fund advantage: Are Canadians overpaying their mutual funds, J. Pension Mngt. 1 (2008), 64-71. DOI: $10.2139 /$ ssrn. 1618830

[12] J. Gil-Bazo, P. Ruiz-Verdú, AA. Santos, The performance of socially responsible mutual funds: The role of fees and management companies, J. Bus. Eth. 94(2) (2010), 243-263. DOI: 10.1007/s10551-0090260-4 
[13] M, Alda, L, Ferruz, The Role of Fees in Pension Fund Performance. Evidence from Spain, Czech J.

Econ. Fin. 62(6) (2012), 518-535.

[14] J. Lakonishok, A. Shleifer, R.W. Vishny, Contrarian investment, extrapolation, and risk, NBER Working Paper No. 4360, 1993, DOI: 10.3386/w4360

[15] G. Brown, P. Draper, E. McKenzie, Consistency of UK pension fund investment performance, J. Bus. Fin. \& Acc. 24(2) (1997), 155-178. DOI: https://doi.org/10.1111/1468-5957.00100

[16] A. Thomas, I. Tonks, Equity performance of segregated pension funds in the UK, J. Asst. Mngt. 1(3) (2001), 321-343. DOI: 10.1057/palgrave.jam.2240025

[17] P. Antolin, Pension fund performance, OECD Working Papers on Insurance and Private Pensions No. 20, OECD Publishing, Paris (2008) DOI: $10.1787 / 240401404057$

[18] R. Lieksnis, Evaluating the financial performance of Latvian and Estonian second-pillar pension funds, Res. in Econ. \& Bus. 2(2) (2013), 54-70.

[19] M. Rashid, W.K.C. San, Employee Provident Funds' Market Performance: The Case of Malaysia, in: E. Ghazali, D.S. Mutum, M. Rashid, J.U. Ahmed (Eds.), Management of Shari'ah Compliant Businesses: Case studies on creating sustainable value, Springer, Cham 2019, pp. 45-54. DOI:

https://doi.org/10.1007/978-3-030-10907-3_5

[20] Z. Ahmad, E. Nor, Pension Fund Performance in East Asia: A comparative study, Eurasian J. Econ. \& Fin. 3(2) (2015) 42-61.

DOI: $10.15604 /$ ejef.2015.03.02.005

[21] E.F. Fama, K.R. French, Common risk factors in the returns on stocks and bonds, J. Fin. Econ. 33(1) (1993), 3-56. DOI: https://doi.org/10.1016/0304405X(93)90023-5.

[22] E.F. Fama, K.R. French, A five-factor asset pricing model, J. Fin. Econ. 116(1) (2015), 1-22. DOI:

https://doi.org/10.1016/j.jfineco.2014.10.010 